\title{
Introduction
}

\section{Politicization of administrative elites in Western Europe: an introduction}

Acta Politica (2016) 51, 407-412. doi:10.1057/s41269-016-0020-2

The aim of this special issue is to analyze the trends of politicization for several categories of administrative elites that are appointed to their position, ranging from civil servants and policy advisors to junior ministers, in several Western European countries. Most of the current literature on government, bureaucracies, political parties, and state institutions in Europe suggests a trend toward increasing politicization of appointments of administrative elites. This suggestion about growing politicization of state administrations comes from two broad fields of political science, studies of political parties and party organizations and the studies of public administration. The party politics literature emphasizes that European parties have undergone dramatic organizational changes over the last four decades: from mass or catch-all structures to cartel, media, or modern cadre parties (Duverger, 1954; Kircheimer, 1966; Koole, 1994; Katz and Mair, 1995; Hopkin and Paolucci, 1999; Krouwel, 2006). This organizational transformation of parties has led to their loss of grounding in society and a corresponding increase of parties' role and position within the institutions of the state. As a result, political parties are supposedly in greater need to appoint people to positions within public life (Mainwaring and Scully, 1995; van Biezen, 2003; van Biezen and Kopecký, 2007, 2014; Gherghina, 2014). Through the appointment of party personnel to key agencies and institutions, parties pursue a twofold goal: reward of faithful supporters and activists (Müller, 2000; Peters and Pierre, 2004; O'Dwyer, 2006; Grzymala-Busse, 2007) and control of state institutions for policy purposes (Kopecký et al, 2012, 2016; Meyer-Sahling and Jager, 2012).

The public administration literature emphasizes the disjuncture between preferences of politicians and bureaucrats as the potential source of politicization. It uses the principal-agent theory to outline and explain this disjuncture. The political government or political parties (principals) can have divergent interests from the officials in the civil service (agents). The difference between the desired and implemented policies is due to the executive control over bureaucracy (Huber and Lupia, 2001). Under these circumstances, the freedom of principals in choosing the agents determines the types of relations (Dahlström et al, 2010). Following this line of reasoning, most research has focused on the political influence over 
appointments in the administration (Hood and Lodge, 2006) and aimed to assess the extent of politicization - broadly conceived as the substitution of political for merit-based criteria (Peters and Pierre, 2004) - in various bureaucracies.

Some empirical work approached the issue from a longitudinal perspective and concluded that politicization has indeed increased in West European countries in the last three decades (Maor, 1999; Peters and Pierre, 2004; Dahlström and Niklasson, 2013). Other studies on European countries used cross-country analyses and concluded that Eastern Europe in particular is plagued by high levels of politicization, driven mainly by legacies of the communist regimes (Goetz and Wollmann, 2001; Verheijen, 2003; Scherpereel, 2004; Meyer-Sahling, 2008). Importantly, however, most empirical studies find a great variation in the levels of politicization of administrative elites. In their study dedicated to Western Europe, for example, Page and Wright (1999) found significant differences regarding the modes and depth of politicization. They identify several empirical patterns of political influence: largely de-politicized bureaucracies (Denmark and the UK), political appointments targeting only leading bureaucratic positions (France and Germany), and the heavy use of party appointments across and deep into various bureaucracies (Italy and Spain). Similarly, focusing on post-communist Europe, Kopecký and Spirova (2011) find significant variation in the level of politicization of the state between the Czech Republic (low to moderate), Hungary (moderate), and Bulgaria (high) but, importantly, also among different types of institutions and policy sectors in each country.

These observations and empirical patterns indicate that politicization may occur to a different degree, vary among state institutions and policy sectors, and target different categories of appointed administrative elites. It is exactly this potential variation that is at the heart of articles assembled in this volume. The studies assembled here are not guided by a tight analytical or conceptual framework of politicization. Instead, the authors were encouraged from the outset to adopt their own analytical approach in what are all single-case studies of individual western European countries. However, our intention from the outset was to guide the authors so as to contribute to the research on politicization of civil service and other public institutions at least in (one of the) three aspects: firstly, by utilizing and critically evaluating various operationalization of politicization and their associated empirical indicators; second, by exploring and empirically documenting similarities and differences in background of various (political) appointees, probing in particular the socio-demographic characteristics, bureaucratic experience, sectoral expertise, and party profile of the appointees; third, by exploring patterns of political recruitment to non-elective offices of the state over time, thus providing a useful comparative perspective on politicization of the state in individual western European countries.

This special issue gathers single-case studies of individual countries in several Western European countries: Germany, Iceland, Italy, the Netherlands, Portugal, 
and Spain. The countries were selected to ensure variation regarding the type of political system, history of politicization, and ways to appoint administrative elites. The selection also ensures a broad geographical coverage.

The contribution of Gunnar Helgi Kristinnsson explains the overall process of political appointments in Iceland building on the three types of vulnerabilities that increased the necessity of politicians and parties to rely on trusted employees in the public sector. The changes in media, changes in the way party organizations are run, and administrative reforms have different mechanisms through which they require a stronger political control of public office. His analysis shows how politicization is the result of the tension between political control and bureaucratic autonomy.

Julia Fleischer analyzes the patterns of bureaucratic tenure in Germany at national level from the perspective of delegation theory and Public Service Bargain. The main argument is that both partisan and professional characteristics influence the bureaucratic tenure. The findings add relevant nuances to existing knowledge about the process. While partisan features matter, officials affiliated with the minister's party have a higher risk of dismissal compared to all other officials. Professional characteristics such as prior experience in managing bureaucratic apparatuses decrease the risk of dismissal. One important result is that professional experience appears to have a higher weight than partisan affiliation in dismissing senior civil servants. Looking at the same category of senior civil servants, Laurenz Ennser-Jedenastik investigates the motivations behind the party politicization of civil service in the Netherlands. The country has a level of politicization that appears to be driven by the demand for ideological agreement and a consociational quest for the representation of the 'pillar parties' in the senior civil service.

The following three articles in the special issue explore the appointment of ministers, junior ministers, and minister advisers in various political contexts. In her study of German ministers, Nora Dörrenbächer investigates the exchange of personnel between private and public sectors and seeks to identify which factors contribute to ministers' side switching. The side switching from public to private office increased since 1949 considerably and it happens much more often than the other way around (from private to public). The main findings indicate that ministers use their political careers as a springboard for well-paid jobs in the private sector. At the same time, education, experience, or party ideology have little or no influence on the decision to join politics from the private sector.

José Real-Dato and Juan Rodríguez-Teruel use the principal-agent theory to explain the content of the delegation relationship between junior ministers, on the one side, and cabinet ministers and the prime minister, on the other side, in Spain. Their analysis focuses on recruitment patterns to identify the extent to which junior ministers tend to focus on policy outputs, party building, or political projection and management. The results suggest that policy outputs are at the core, with expertise 
as a dominant factor of recruitment feature. Fabrizio di Mascio and Alessandro Natalini take a close look at the appointment of ministerial advisers in Italy and identify three patterns of institutional stability. Their analysis combines career pathways and expert interviews and reveals that the realignment of the party system has not led to a pattern of radical change in Italy. The legacy of stable administrative structures has allowed for a gradual change with respect to ministerial advisers' policy competence and political loyalty.

The article of Patrícia Silva and Carlos Jalali investigates the party patronage in Portugal by exploring the logics of recruitment on three inter-related dimensions: the extent to which hierarchical levels are associated to patronage functions, the extent to which different moments of the governing period are associated to different faces of patronage, and the impact of party competition on patterns and logics of recruitment to the civil service. The empirical evidence brings an important contribution to the study of patronage by showing its multi-faceted and multi-layered character. Party control over policy-making focuses mainly on highlevel managerial positions, while the rewarding of partisan loyalists is visible at lower level positions. The authors also show how patronage can be a function of the importance of position and governing period with top positions being appointed at the beginning of the term in office, while appointments to the middle management structure occur more toward the end of the governing period.

Draft versions of all these articles have been presented at the ECPR Joint Session of Workshops in Mainz 2013. It has taken quite some time before we managed to turn them into what we hope is a valuable collection of papers on an important topic. We would like to express our thanks to all the participants of the workshop, as well as the anonymous reviewers of this journal for their comments on these articles and their contribution to the general discussion of politicization of public institutions. Our biggest thanks goes to our contributors, for writing very interesting studies, and for being willing to work under a series of tight deadlines.

\section{References}

Dahlström, C., Lapuente, V. and Teorell, J. (2010) Dimensions of Bureaucracy A Cross-National Dataset on the Structure and Behavior of Public Administration. QoG Working Paper Series, 13, pp.3-59.

Dahlström, C., and Niklasson, B. (2013) The politics of politicization in Sweden. Public Administration 91(4): 891-907.

Duverger, M. (1954) Political Parties: Their Organization and Activity in the Modern State. London: Lowe and Brydone.

Gherghina, S. (2014) Party Organization and Electoral Volatility in Central and Eastern Europe: Enhancing Voter Loyalty. London: Routledge.

Goetz, K.H. and Wollmann, H. (2001) Governmentalizing central executives in post-communist Europe: a four-country comparison. Journal of European Public Policy 8(6): 864-887.

Grzymala-Busse, A. (2007) Rebuilding Leviathan: Party Competition and State Exploitation in PostCommunist Democracies. Cambridge: Cambridge University Press. 
Hood, C. and Lodge, M. (2006) The Politics of Public Service Bargains: Reward. Oxford: Oxford University Press.

Hopkin, J. and Paolucci, C. (1999) The party as business firm: Cases from Spain and Italy. European Journal of Political Research 35(2): 307-339.

Huber, J.D. and Lupia, A. (2001). Cabinet instability and delegation in parliamentary democracies. American Journal of Political Science 45(1): 18-32.

Katz, R.S. and Mair, P. (1995) Changing models of party organization and party democracy: The emergence of the cartel party. Party Politics, 1(1): 5-28.

Kircheimer, O. (1966) The transformation of the Western European party system. In J. LaPalombara and M. Weiner (eds.), Political Parties and Political Development (pp. 177-200). Princeton: Princeton Univeristy Press.

Koole, R. (1994) The vulnerability of the modern cadre party in the Netherlands. In R. S. Katz and P. Mair (Eds.), How Parties Organize: Change and Adaptation in Party Organizations in Western Democracies (pp. 278-303). London: Sage.

Kopecký, P., Mair, P. and Spirova, M. (eds.). (2012) Party Patronage and party Government in European Democracies. Oxford: Oxford University Press.

Kopecký, P., Meyer-Sahling, J.H., Panizza, F., Scherlis, G., Schuster, C., and Spirova, M. (2016) Party patronage in contemporary democracies: Results from an expert survey in 22 countries from five regions. European Journal of Political Research, 55(2): 416-431.

Kopecký, P. and Spirova, M. (2011) "Jobs for the boys"? Patterns of party patronage in post-communist Europe. West European Politics 34(5): 897-921.

Krouwel, A. (2006) Party Models. In R. S. Katz and W. Crotty (eds.), Handbook of Party Politics (pp. 249-269). London: Sage Publications.

Mainwaring, S. and Scully, T. R. (eds.) (1995) Building Democratic Institutions: Party Systems in Latin America. Stanford: Stanford University Press.

Maor, M. (1999) Recruitment and training of senior civil servants in Germany and the UK, 1970-1995: The impact of new public management and European integration. Current Politics and Economics of Europe 8(4): 341-355.

Meyer-Sahling, J.-H. (2008) The changing colours of the post-communist state: The politicisation of the senior civil service in Hungary. European Journal of Political Research 47(1): 1-33.

Meyer-Sahling, J.-H. and Jager, K. (2012) Party Patronage in Hungary: Capturing the State. In P. Kopecky, P. Mair, and M. Spirova (eds.), Party Patronage in Contemporary European Democracies (pp. 163-185). Oxford: Oxford University Press.

Müller, W. (2000) Patronage by national governments. In J. Blondel and M. Cotta (eds.), The Nature of Party Government: A Comparative European Perspective (pp. 141-160). Basingstoke: Palgrave.

O'Dwyer, C. (2006) Runaway State-Building: Patronage Politics and Democratic Development. Baltimore: Johns Hopkins University Press.

Page, E., and Wright, V. (eds.) (1999) Bureaucratic Elites in Western European States: A Comparative Analysis of Top Officials in Eleven Countries. Oxford: Oxford University Press.

Peters, G.B., and Pierre, J. (2004) Politicization of the Civil Service in Comparative Perspective. London: Routledge.

Scherpereel, J. A. (2004) Renewing the socialist past or moving towards the European administrative space? Inside Czech and Slovak ministries. Administration and Society 36(5): 553-593.

van Biezen, I. (2003) Political Parties in New Democracies. Houndmills: Palgrave Macmillan.

van Biezen, I. and Kopecký, P. (2007) The state and the parties: Public funding, public regulation and rent-seeking in contemporary democracies. Party Politics 13(2): 235-254. 
van Biezen, I. and Kopecký, P. (2014) The cartel party and the state: Party-state linkages in European democracies. Party Politics 20(2): 170-182.

Verheijen, T.J.G. (2003) Public administration in post-communist states. In G.B. Peters and J. Pierre (eds.), Handbook of Public Administration (pp. 489-499). London: Sage.

Sergiu Gherghina

Goethe University Frankfurt, Frankfurt, Germany

Petr Kopecký

Leiden University, Leiden, The Netherlands

E-mail: KOPECKY@FSW.leidenuniv.nl 